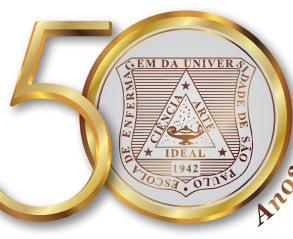

\title{
Productivity versus workloads in the nursing working environment*
}

\author{
A produtividade versus cargas de trabalho no ambiente laboral da enfermagem \\ La productividad versus cargas de trabajo en el marco laboral de la enfermería
}

Deciane Pintanela de Carvalho ${ }^{1}$, Laurelize Pereira Rocha ${ }^{1}$, Jamila Geri Tomaschewski-Barlem¹, Edison Luiz Devos Barlem¹, Diana Cecagno², Graziele de Lima Dalmolin ${ }^{3}$

How to cite this article:

Carvalho DP, Rocha LP, Tomaschewski-Barlem JG, Barlem ELD, Cecagno D, Dalmolin GL. Productivity versus workloads in the nursing working environment. Rev Esc Enferm USP. 2017;51:e03301. DOI: http://dx.doi.org/10.1590/S1980-220X2017028903301

"Extracted from the dissertation "Cargas de trabalho e perda de produtividade dos trabalhadores de enfermagem: estudo em um hospital universitário", Programa de PósGraduação em Enfermagem, Universidade Federal do Rio Grande, 2016.

${ }^{1}$ Universidade Federal de Rio Grande, Rio Grande, Rio Grande do Sul, Brazil.

${ }^{2}$ Universidade Federal de Pelotas, Pelotas, Rio Grande do Sul, Brazil.

${ }^{3}$ Universidade Federal de Santa Maria, Santa Maria, Rio Grande do Sul, Brazil.

\begin{abstract}
Objective: To analyze the association between the productivity loss of nursing workers and workloads in a teaching hospital. Method: Descriptive study with a quantitative approach, conducted with nursing workers. A structured data collection instrument and the Work Limitations Questionnaire were used. Data analysis was performed using descriptive and analytical statistics, with the Kruskal Wallis test and the Spearman rank correlation. Results: A total of 211 nursing workers participated in the study. They had an average of $6.38 \%$ of lost productivity; $75 \%$ of nursing technicians showed $9.57 \%$ of productivity loss, followed by nurses $(8.75 \%)$ and nursing aides $(8.50 \%)$. The units presenting the highest productivity loss were surgical clinic (8.81\%), and medical clinic $(8.58 \%)$. The rate of productivity loss was significantly associated with chemical loads $(p=0.044)$ and with mechanical loads $(p=0.041)$. Conclusion: Workers presented productivity loss and work limitations associated with workloads, which shows they have difficulty performing the activities in part of the work time.
\end{abstract}

DESCRIPTORS

Nursing, Team; Workload; Burnout, Professional; Presenteeism; Occupational Health.

Corresponding author:

Deciane Pintanela de Carvalho

Universidade Federal do Rio Grande

Rua General Osório, s/n

CEP 96200-190 - Rio Grande,

Rio Grande do Sul, Brazil

deciane.carvalho@gmail.com 


\section{INTRODUCTION}

Productivity loss is related to problems in the performance of activities, such as difficulties in meeting deadlines, and concentration deficits, which prevent workers from thinking clearly, making them likely to make mistakes and unable to complete the physical demands of their work ${ }^{(1)}$. This productivity loss may be inherent to presenteeism, characterized by workers who, despite physical or mental problems related to work, continue to perform their activities, but with reduced productivity and performance ${ }^{(2)}$.

The nursing work process exposes workers to different workloads, which cause physical and mental exhaustion, leading to productivity loss ${ }^{(3)}$. Workloads act directly and indirectly on workers' health ${ }^{(4)}$ and are characterized as external and internal materiality loads. The former is identified by the physical, chemical, biological and mechanical loads, and the latter by the physiological and psychic loads ${ }^{(5)}$.

In nursing, changes in temperature and ionizing radiation are examples of physical loads; handling of chemicals and medicines, in general, are chemical loads; exposure to patients' body fluids, among others, are examples of biological loads ${ }^{(6)}$; labor accidents and physical violence are mechanical loads; physiological loads include working in the standing position, uncomfortable and inadequate postures, night work and manipulation of excessive weight ${ }^{(7)}$; and, among psychic loads, lack of autonomy, abuse of power, moral harassment, institutional pressure stand out ${ }^{(8)}$.

The constant exposure of workers to workloads can lead to sickness, removal from the institution, and the decrease in capacity to perform activities ${ }^{(7)}$. Another factor is presenteeism, in which a great number of nursing team workers can be present at work, even when presenting physical and mental limitations, which reduce their productivity ${ }^{(9)}$.

The presence of workers in these conditions will lead to health loss. In addition, there is the possibility of the occurrence of errors, which impair the quality of care and the performance of work activities ${ }^{(10)}$. The main limitations related to nursing workers productivity loss are the physical demands, which affect the nursing workers' bodies, due to physical efforts during the provision of care, and the mental demands comprising the difficulties workers have in performing cognitive tasks, as well as working and interacting with people (11) $^{(1)}$

Considering that workloads are responsible for nursing workers' illnesses, it is necessary to investigate the association between work productivity loss and workloads, because these directly influence workers' health and the development of quality care. Therefore, the aim of this study was to analyze the association between productivity loss and workloads of nursing workers in a teaching hospital.

\section{METHOD}

\section{Study TYPE}

This is a descriptive study with a quantitative approach, carried out with nursing workers in a teaching hospital in the south of the state of Rio Grande do Sul.

\section{DATA SOURCE}

For the sample calculation, the functional picture of the teaching hospital in the data collection period, consisting of 355 nursing workers, was considered. The StatCalc of the EpiInfo software, version 7, was used, with a 95\% confidence level, and a minimum sample of 184 participants. Sample selection took place in a non-probabilistic way for convenience. Thus, 211 nursing workers participated in this study, namely 49 nurses, 85 nursing technicians, and 77 nursing aides.

The participants' inclusion criterion was having worked at least 3 months in the institution. The exclusion criteria were to work in administrative positions, and be on medical leave, another leave of any nature, or on vacation at the time of data collection.

\section{Data collection}

Data collection was performed from July to August 2016, covering the morning, afternoon and evening shifts, by a previously trained data collection team. This team participated in two meetings held before the beginning of data collection. At the first meeting, the research theme, objectives, questionnaires, ethical aspects, and signing of the informed consent form were addressed.

In a second moment, guidance was given on the approach of the workers, establishing schedules for data collection that did not influence the routine of the studied sectors, avoiding the schedules of duty change. Nursing workers were approached in the work sectors, and invited to participate in the study. Following the clarification about the research objective, the participants chose to fill in the form at that moment, or to schedule the best date to return it.

A structured data collection instrument was used, consisting of questions related to the characteristics of the worker (gender, age, educational level); job characteristics (professional category, work sector, extra-hours per week, and work shift and period); and work process-related workloads (presence, type and Likert scale for checking the frequency of loads, with levels always, often, sometimes, rarely, and never).

In addition, the Work Limitations Questionnaire (WLQ) was used, consisting of 25 items that assess the frequency of difficulty or ability to perform work tasks, distributed in four domains of limitation in the work: time management, physical demand, interpersonal mental demand, and production demand ${ }^{(12)}$. This questionnaire was validated, translated into Portuguese and culturally adapted to the Brazilian reality ${ }^{(13)}$. The WLQ can only be used with permission by the authors ${ }^{(12)}$, and such permission required the signature of a Confidentiality Disclosure Agreement.

The WLQ consists of scales, which have a score ranging from zero (limited none of the time) to 100 (limited all of the time), indicating the percentage of time workers had limitations at work. Finally, the WLQ index is calculated, determining the percentage of workers' productivity loss at work. The WLQ domains have their own score, and the average of the completed items is then calculated. The rule 
of a minimum number of responses in each domain is considered, which allows the other calculations to determine the limitation ${ }^{(12)}$.

\section{Data ANALYSIS}

Data were entered and organized using the double typing technique for data quality control, and then submitted to statistical analysis using the Statistical Package for the Social Sciences (SPSS) software, version 21. After database entry, the calculations were performed to determine the values corresponding to the indices of productivity loss. In the domains, values according to participants' answers were assigned; because two of them did not fill the WLQ scales with the minimum number of responses required for WLQ analysis, two questionnaires were excluded.

Qualitative variables were described by means of absolute and relative frequencies; for the quantitative variables, a descriptive analysis was performed through mean, standard deviation, median, interquartile range, maximum and minimum values. In the analytical analysis, the normality of the numerical data was tested by means of the KolmogorovSmirnov Test, and it was noted that the data did not show a normal distribution; therefore, non-parametric tests were used to analyze the results. The Kruskal Wallis test was used for variables with more than one category, and also the Spearman's rank correlation coefficient, which checks the strength of a linear relationship between two variables.
A p-value $<0.05$ was adopted as statistical significance in all analyses ${ }^{(14)}$.

\section{ETHICAL ASPECTS}

This study is part of the macroproject "Work process and nursing worker's health", approved by a health research ethics committee, under no. 54/2016, and observed the recommendations of Resolution 446/12 of the National Health Council, on research involving human subjects. All participants signed an informed consent form.

\section{RESULTS}

Of the 211 participants, 188 (89.1\%) were female, and $23(10.9 \%)$ were male, their median age was 41 years, with a minimum age of 23 years and a maximum of 68 years. Regarding working time in nursing care, nursing workers had a minimum of 1 year and 1 month, and a maximum of 38 years and 2 months, with an average of 15 years and 3 months, 92 (43.6\%) workers worked extra-hours every week.

Regarding productivity loss, according to Table 1, nursing workers had a mean of $6.38 \%$ productivity loss, of which $75 \%$ had up to $8.89 \%$ of productivity loss. In addition, $75 \%$ of the workers presented a $50 \%$ limitation in the physical demand area, which shows that, in part of the time, the workers had difficulty performing activities that required the repetition of movements during work, as well as continuously remaining in the same position.

Table 1 - Distribution of nursing workers according to the values achieved in items of the WLQ - Rio Grande do Sul, Brazil, 2016.

\begin{tabular}{|c|c|c|c|c|c|c|}
\hline WLQ* Domains & $\mathbf{N}$ & Mean & $\mathbf{S d}^{+}$ & $\mathrm{Q1}^{\ddagger}$ & Med $^{\S}$ & $Q^{\prime \prime \prime}$ \\
\hline WLQ* index & 209 & 6.38 & 5.16 & 2.65 & 4.69 & 8.89 \\
\hline Time management & 209 & 26.83 & 25.52 & 6.25 & 15 & 40 \\
\hline Physical demand & 209 & 32.46 & 23.74 & 12.50 & 29.17 & 50 \\
\hline Mental-interpersonal demand & 209 & 20.49 & 22.71 & 3.13 & 13.89 & 27.95 \\
\hline Output demand & 209 & 22.02 & 24.23 & 5 & 15 & 30 \\
\hline
\end{tabular}

Work Limitations Questionnaire; ${ }^{\dagger}$ Standard deviation; ${ }^{\ddagger} 1^{\text {st }}$ Quartile; ${ }^{\S}$ Median; ${ }^{\|} 3^{\text {rd }}$ Quartile.

Note: $n=209$

Table 2 shows the average productivity loss of nursing workers by professional categories and by work sectors. It was observed that the average productivity loss among the professional categories presented little variation; however, $75 \%$ of the nursing technicians had a $9.57 \%$ productivity loss at work, followed by an $8.75 \%$ loss by the nurses, and an $8.50 \%$ by nursing aides. This means that these workers had difficulty performing work tasks, such as handling equipment, concentrating on work, completing activities, and exchanging information with co-workers and patients.

Considering the work sectors, it was observed that $75 \%$ of workers in the clinical surgical unit presented a productivity loss index of $14.94 \%$, and the workers of the medical unit presented an index of $11.86 \%$. This can be justified by the fact that these units have a high demand for care, with hospitalization for adult patients in pre- and post-operative situations in the surgical unit, and hospitalization for adult patients with physical impairment, in situations of chronic diseases, infectious diseases, and palliative care in the clinical unit.

Seventy-five percent of the workers had a lower rate of productivity loss in the surgical center units $(4.90 \%)$, and in the neonatal intensive care unit $(5.55 \%)$. These results can be related to the fact that the sectors are configured as a closed workplace, with limited access to the public and greater circulation of professionals. 
Table 2 - Distribution of nursing workers per professional category and work sector, according to the WLQ Index - Rio Grande do Sul, Brazil, 2016.

\begin{tabular}{|c|c|c|c|c|c|c|c|c|}
\hline \multirow{2}{*}{ Variables } & \multirow{2}{*}{$\mathbf{n}$} & \multicolumn{7}{|c|}{ WLQ Index } \\
\hline & & Min. & Max. & Mean & $\mathrm{Sd}^{+}$ & $\mathrm{Q1}^{ \pm}$ & Med $^{\S}$ & Q3।I \\
\hline \multicolumn{9}{|l|}{ Professional category } \\
\hline Nurses & 49 & 0.80 & 21.70 & 6.20 & 4.53 & 2.95 & 4.50 & 8.75 \\
\hline Nursing technicians & 84 & 0 & 23.51 & 6.56 & 5.12 & 2.65 & 4.88 & 9.57 \\
\hline Nursing aides & 76 & 0 & 22.59 & 6.30 & 5.62 & 2.27 & 4.36 & 8.50 \\
\hline \multicolumn{9}{|l|}{ Work sector } \\
\hline Surgical clinic unit & 21 & 1.16 & 17.84 & 8.81 & 5.67 & 3.89 & 7.65 & 14.94 \\
\hline Medical clinic unit & 21 & 1.49 & 15.89 & 8.58 & 4.05 & 4.99 & 8.69 & 11.86 \\
\hline Trauma unit & 11 & 1.72 & 21.70 & 7.98 & 6.68 & 2.28 & 7.08 & 9.11 \\
\hline Pediatrics & 14 & 1.79 & 23.51 & 7.82 & 7.16 & 2.64 & 5.03 & 10.91 \\
\hline Emergency service & 24 & 0 & 22.22 & 7.06 & 6.25 & 2.40 & 5.48 & 10.57 \\
\hline Maternity & 16 & 0 & 20.40 & 5.47 & 5.49 & 1.89 & 3.53 & 7.61 \\
\hline Obstetrics & 13 & 0.90 & 14.53 & 5.46 & 4.76 & 1.76 & 3.60 & 8.41 \\
\hline General intensive care unit & 12 & 0 & 13.12 & 5.13 & 3.79 & 2.34 & 4.50 & 8.16 \\
\hline Neonatal intensive care unit & 37 & 0.24 & 18.71 & 4.81 & 4 & 2.49 & 3.81 & 5.55 \\
\hline Material and sterilization center & 6 & 0.90 & 10.90 & 4.24 & 3.60 & 1.46 & 3.43 & 6.57 \\
\hline Operating room & 19 & 0.18 & 13.31 & 3.71 & 3.07 & 2.11 & 2.81 & 4.90 \\
\hline
\end{tabular}

${ }^{\dagger}$ Standard deviation; ${ }^{\ddagger} 1^{\text {st }}$ Quartile; ${ }^{\S}$ Median; $"{ }^{\text {rd }}{ }^{\text {d }}$ Quartile.

Note: $\mathrm{n}=209$.

Regarding the WLQ domains, according to Table 3, it was observed that the professional category of nursing workers presented a statistically significant difference with a limitation in the physical demand domain $\left(\mathrm{x}^{2}=6.62\right.$; $\mathrm{gl}=2 ; \mathrm{p}=0.036)$, evidencing that the workers presented some physical difficulty, such as leaning and stretching to develop their activities. However, the work shift did not present statistical significance with productivity loss, and limitation to work.

The variable work sector presented a significant difference from the limitation in the time management domain $\left(x^{2}=28.28 ; \mathrm{gl}=15 ; \mathrm{p}=0.020\right)$, the physical demand $\left(\mathrm{x}^{2}=32.14\right.$; $\mathrm{gl}=15 ; \mathrm{p}=0.006)$, the output demand $\left(\mathrm{x}^{2}=26.40 ; \mathrm{gl}=15 ; \mathrm{gl}=2\right.$; $\mathrm{p}=0.034)$, and the productivity loss index $\left(\mathrm{x}^{2}=29.34 ; \mathrm{gl}=15\right.$; $\mathrm{p}=0.015$ ), which highlights that the work sector influences the difficulty of workers in meeting the work demand, moving through different locations, and complying with the unit's schedule and routine.

In the Spearman's rank correlation test, the variable work time did not show statistical significance with productivity loss and limitations to work. Weekly extra-hours and WLQ domains showed a significant statistical correlation (0.039) with the limitation in the physical demand domain, identifying that the workers had difficulties in following the work routines, such as moving to provide care to patients, standing, or carrying objects.

Table 3 - Distribution of p-value of the characteristics of the work process regarding WLQ domains - Rio Grande do Sul, Brazil, 2016.

\begin{tabular}{lccccc}
\hline \multirow{2}{*}{ Variable } & WLQ* Index & Time management & Physical demand & $\begin{array}{c}\text { Mental-interpersonal } \\
\text { demand }\end{array}$ & Output demand \\
\cline { 2 - 6 } & $\mathrm{p}$ & $\mathrm{p}$ & $\mathrm{p}$ & $\mathrm{p}$ & $\mathrm{p}$ \\
\hline Professional category & .632 & .969 & $.036^{+}$ & .697 & .638 \\
Work shift & .287 & .111 & .491 & .800 & .502 \\
Work sector & $.015^{+}$ & $.020^{+}$ & $.006^{+}$ & .231 & $.034^{+}$ \\
\hline
\end{tabular}

Work Limitations Questionnaire; ${ }^{\dagger} \mathrm{p}<0.05$.

Note: $\mathrm{n}=209$

In Table 4, there was a significant association between chemical load and productivity loss at work $\left(x^{2}=9.81 ; \mathrm{gl}=4\right.$; $\mathrm{p}=0.044$ ), as well as between chemical load and mental-interpersonal demand limitation $\left(x^{2}=10.41 ; \mathrm{gl}=4 ; \mathrm{p}=0.034\right)$. This aspect is related to debilitation caused by chemical loads, such as irritability, which can reduce concentration at work and hamper interpersonal relationships.

A significant association between physical load and limitation in the physical demand domain $\left(x^{2}=9.80 ; \mathrm{gl}=4\right.$; $\mathrm{p}=0.044)$, psychic load and time management limitation $\left(\mathrm{x}^{2}=6.62 ; \mathrm{gl}=4 ; \mathrm{p}=0.022\right)$, and physiological load and limitation in the time management domain $\left(x^{2}=10.38\right.$; $\mathrm{gl}=4 ; \mathrm{p}=0.034)$ was also observed, which explains the difficulty workers have to perform all the activities during the work period.

Mechanical load had a statistically significant association with productivity loss $\left(x^{2}=9.97 ; g l=4 ; p=0.041\right)$, and with the limitation in the time management domain $\left(x^{2}=11.46 ; g l=4\right.$; $\mathrm{p}=0.010$ ). This association is due to the dynamics and nursing work overload, which allow the occurrence of accidents, generating difficulty to develop activities without breaks or rest, as well as to maintain a work routine. 
Table 4 - Distribution of $\mathrm{p}$-value of WLQ domains according to the workloads in the work environment of the nursing workers - Rio Grande do Sul, Brazil, 2016.

\begin{tabular}{|c|c|c|c|c|c|c|}
\hline \multirow{3}{*}{ WLQ Domains* } & \multicolumn{6}{|c|}{ Workloads } \\
\hline & $\begin{array}{l}\text { Chemical load } \\
(n=205)\end{array}$ & $\begin{array}{l}\text { Physical load } \\
(n=209)\end{array}$ & $\begin{array}{l}\text { Psychic load } \\
(n=208)\end{array}$ & $\begin{array}{l}\text { Physiological load } \\
(n=206)\end{array}$ & $\begin{array}{c}\text { Mechanical load } \\
(n=204)\end{array}$ & $\begin{array}{c}\text { Biological load } \\
(n=208)\end{array}$ \\
\hline & $\mathbf{p}^{+}$ & $\mathbf{p}^{+}$ & $\mathbf{p}^{+}$ & $\mathbf{p}^{+}$ & $\mathbf{p}^{+}$ & $\mathbf{p}^{+}$ \\
\hline WLQ index & $.044^{\ddagger}$ & .139 & .178 & .064 & $.041^{\ddagger}$ & .253 \\
\hline Time management & .124 & .134 & $.022^{\ddagger}$ & $.034^{\neq}$ & $.010^{\ddagger}$ & .339 \\
\hline Physical demand & .845 & $.044^{\ddagger}$ & .965 & .192 & .252 & .902 \\
\hline Output demand & .123 & .171 & .150 & .135 & .219 & .296 \\
\hline
\end{tabular}

Work Limitations Questionnaire; ${ }^{\dagger}$ Kruskal Wallis test; ${ }^{\dagger} \mathrm{p}<0.05$.

Note: $\mathrm{n}=209$.

\section{DISCUSSION}

Nursing workers presented a mean productivity loss of $6.38 \%$, evidencing that part of the teaching hospital's workers provide care with some limitations; in addition, up to $75 \%$ of the workers showed $8.89 \%$ of productivity loss. Other studies ${ }^{(11,15)}$ also showed similar but lower values, with a mean of $5.5 \%$ of productivity loss, with nurses working in the nephrology unit, of whom $75 \%$ presented a productivity loss index of up to $4.84 \%$; nurses providing care to critical and potentially critical patients had an average productivity loss of $3.31 \%$.

It should be emphasized that the greatest limitations of the workers in this study are related to time limitation to perform activities from physical demands, followed by the limitation of time management, output demand, and mental-interpersonal demand. Similar results were found in a WLQ analysis with 129 nurses, showing a limitation of $26.33 \%$ of time to perform activities from physical demand, followed by $11.34 \%$ of the mental-interpersonal demand, $9.1 \%$ of time management, and $8.8 \%$ of output demand ${ }^{(11)}$.

The professional category of nursing technicians presented a higher productivity loss index; however, the values did not differ considerably from the values of nurses and nursing aides. These results are similar to the findings of nurses working in northern Italy, who were identified as the most active workers, presenting physical and mental exhaustion, and consequently productivity loss at work ${ }^{(16)}$.

Regarding work sectors, it was evidenced that the highest index of productivity loss was in the clinical surgical unit, followed by the medical unit. The sites that presented the least productivity loss were the operating room and the neonatal intensive care unit. The occurrence of a higher index of productivity loss in open units, and a lower index in the closed units is confirmed due to the physical and functional structure, and because it presents less vigilance in work performance, and proximity to the other workers, which differs them from closed units ${ }^{(10)}$.

Work shifts and WLQ domains were not significantly associated, which was confirmed in a study with nurses at another teaching hospital, highlighting that work shifts do not affect the evaluation of productivity loss ${ }^{(10)}$. Work time also had no statistically significant correlation with loss of productivity and limitation for work. However, a study ${ }^{(16)}$ with 174 nurses from four small hospitals located in the region of Piedmont, Italy, identified a statistically significant relationship between work time and loss of productivity, contradicting the results found in this study.

There was a correlation between weekly extra-hours and limitation on the domain physical demand. This result may be related to the fact that the profession requires capacity of movement, flexibility, and physical resistance. Due to these needs, workers who exceed the weekly workload can be physically debilitated, which is confirmed in Korean workers who showed a relation between excessive workload and productivity loss at work ${ }^{(14)}$.

In the association between workloads and productivity loss, and WLQ domains, it was observed that chemical loads had significant associations with productivity loss index and with limitation in the mental-interpersonal domain. Chemical loads can generate pruritus, discomfort, and irritability in workers, and visible skin rashes may be embarrassing factors, influencing interpersonal relationships. Such loads are common in the nursing work due to drug manipulation ${ }^{(6)}$. There is evidence that nursing workers may present cutaneous reactions when reconstituting antibiotics, with pruritus and rashes as symptoms ${ }^{(17)}$.

Physical workloads had a significant association with the domain of physical limitation. This workload is characterized by exposure of workers to ionizing and non-ionizing radiations, temperature differences, noise, among others ${ }^{(5)}$. The noise perceived in the nursing work environment is due to patient monitoring devices and infusion pumps, which can cause discomfort to workers, to the point of impacting productivity and capacity to work ${ }^{(18)}$. Irritability during work is an impairment resulting from this load ${ }^{(6)}$, which can cause tension and decrease workers' physical and mental willingness.

Limitation in the time management domain is related to the difficulty workers have to comply with schedules and to perform the tasks within the expected time ${ }^{(12)}$. In this study, there was a significant association of the time management domain with the psychic loads present in the nursing work environment, which can be identified by excessive work demands. This condition is confirmed among nurses in basic care units in Maracanaú, Brazil, who, due to the excess of daily care activities, presented difficulties in carrying out 
tasks involving planning, coordination, and organization of care ${ }^{(19)}$.

Another significant association with the limitation in the time management domain was the physiological loads, which may be related to the workers' limitations that prevent them from performing the activities in the period of time they previously performed them, consequently reducing their productivity. These loads are identified through the performance of activities in the standing position, inadequate positions, manipulation and weight transport, and may be responsible for work-related musculoskeletal diseases ${ }^{(7,20)}$. A study ${ }^{(21)}$ with 296 Portuguese nurses identified musculoskeletal diseases in $46.1 \%$ of the participants as those that showed the greatest relationship with presenteeism, evidenced by productivity loss.

Time management and mechanical load domains also showed a significant association, as well as mechanical loads and productivity loss. These workloads can be represented by work accidents with sharp materials and physical violence ${ }^{(7)}$. Work accidents cause physical and psychological damage to workers, who seek to carry out nursing care more cautiously, as a way to prevent accidents from occurring again ${ }^{(22)}$; this may require more time for the development of tasks, leading to a decrease in productivity and performance of activities.

The study's cross-sectional design can be considered a limitation, as it does not allow the establishment of causal relationships, even in statistically significant associations.
Another limitation was the study development in a single workplace, which does not allow the generalization of the results among the nursing workers.

The results found contribute to the scientific knowledge, allowing a discussion about the issues of productivity loss and workloads. This fact allows the search for strategies to change behaviors and attitudes on the part of nursing workers, managers, professors, and students linked to the institutions, with the purpose of changing the work reality, because situations that require interventions have been identified.

\section{CONCLUSION}

The study led to the conclusion that the nursing workers at the studied teaching hospital showed workload-associated productivity loss, and limitations to work that are stronger than those presented in the literature, demonstrating that these workers have difficulty performing the activities in part of the time. Productivity loss may be related to nursing workers illnesses and impairment due to the workloads in the work environment.

Thus, the results have identified, through productivity loss, a negative impact of workloads on workers' health that, consequently, impact patient care. Based on this association between productivity loss and workloads, the need for new studies that contribute to the investigation about the relationship between productivity and work-related accidents, impairments, and nursing work-related diseases is reinforced.

\section{RESUMO}

Objetivo: Analisar a associação entre a perda de produtividade dos trabalhadores da enfermagem e as cargas de trabalho em um Hospital Universitário. Método: Estudo descritivo com abordagem quantitativa, realizado com trabalhadores de enfermagem. Utilizouse de um instrumento de coleta de dados estruturado e o Work Limitations Questionnaire. A análise de dados ocorreu por meio de estatística descritiva e analítica, com os testes Kruskal Wallis e correlação de Rho de Spearmam. Resultados: Participaram do estudo 211 trabalhadores da enfermagem. Os trabalhadores apresentaram média de 6,38\% de produtividade perdida, 75\% dos técnicos de enfermagem possuíram 9,57\% de perda de produtividade, seguido dos enfermeiros $(8,75 \%)$ e auxiliares de enfermagem $(8,50 \%)$. As Unidades que apresentaram maior produtividade perdida foram Clínica Cirúrgica $(8,81 \%)$ e Clínica Médica (8,58\%). O índice de perda de produtividade apresentou associação significativa com as cargas químicas ( $p=0,044)$ e com as cargas mecânicas ( $p=0,041$ ). Conclusão: Os trabalhadores apresentaram perda de produtividade e limitações para o trabalho associadas às cargas de trabalho, o que demonstra que possuem dificuldade para a realização das atividades em parte do tempo de trabalho.

\section{DESCRITORES}

Equipe de Enfermagem; Carga de Trabalho; Esgotamento Profissional; Presenteísmo; Saúde do Trabalhador.

\section{RESUMEN}

Objetivo: Analizar la asociación entre la pérdida de productividad de los trabajadores de la enfermería y las cargas de trabajo en un Hospital Universitario. Método: Estudio descriptivo con abordaje cuantitativo, llevado a cabo con trabajadores de enfermería. Se utilizó un instrumento de recolección de datos estructurado y el Work Limitations Questionnaire. El análisis de datos ocurrió por medio de estadística descriptiva y analítica, con las pruebas Kruskal Wallis y correlación de Rho de Spearmam. Resultados: Participaron en el estudio 211 trabajadores de la enfermería. Los trabajadores presentaron promedio del 6,38\% de productividad perdida, el $75 \%$ de los técnicos de enfermería tuvieron el 9,57\% de pérdida de productividad, seguido de los enfermeros (el 8,75\%) y auxiliares de enfermería (el 8,50\%). Las Unidades que presentaron mayor productividad perdida fueron Clínica Quirúrgica (8,81\%) y Clínica Médica (8,58\%). El índice de pérdida de productividad presentó asociación significativa con las cargas químicas ( $\mathrm{p}=0,044)$ y con las cargas mecánicas $(\mathrm{p}=0,041)$. Conclusión: Los trabajadores presentaron pérdida de productividad y limitaciones para el trabajo asociadas con las cargas de trabajo, lo que demuestra que tienen dificultad para la realización de las actividades en parte del tiempo laboral.

\section{DESCRIPTORES}

Grupo de Enfermería; Carga de Trabajo; Agotamiento Profesional; Presentismo; Salud Laboral. 


\section{REFERENCES}

1. Sanderson K, Cocker F. Presenteeism: implications and health risks. Aust Fam Physician [Internet]. 2013 [cited 2017 Nov 13];26(4):172-5. Available from: http://www.racgp.org.au/afp/2013/april/presenteeism/

2. Laranjeira CA. O contexto organizacional e a experiência de stress: uma perspectiva integrativa. Rev Salud Pública [Internet]. 2009 [citado 2017 nov. 13];11(1):123-33. Disponível em: http://www.scielosp.org/pdf/rsap/v11n1/v11n1a13.pdf

3. Felli VEA, Baptista PCP, Mininel VA, Sarquis LMM. Indicators to surveillance the health of nursing staff. Occup Environ Med. 2013;70:A1-A149.

4. Rocha LP, Cezar-Vaz MR, Almeida MCV, Borges AM, Silva MS, Sena-Castanheira J. Workloads and occupational accidents in a rural environment. Texto Contexto Enferm [Internet]. 2015 [cited 2017 Nov 13];24(2):325-35. Available from: http://www.scielo.br/pdf/tce/ v24n2/0104-0707-tce-24-02-00325.pdf

5. Kirchhof ALC, Lacerda MR, Sarquis LMM, Magnago TSB, Gomes IM. Compreendendo cargas de trabalho na pesquisa em saúde ocupacional na enfermagem. Colomb Med. 2011;42(1):113-1.

6. Flôr RC, Gelbcke FL. Analysis of workloads due to the praxis of nursing aiming the hemodynamic service. Rev Enferm UFPE Online [Internet]. 2013 [cited 2017 Nov. 13];7(n.esp):7034-41. Available from: http://www.revista.ufpe.br/revistaenfermagem/index.php/revista/ article/view/3338/pdf_4240

7. Felli VEA. Condições de trabalho de enfermagem e adoecimento: motivos para a redução da jornada de trabalho para 30 horas. Enferm Foco [Internet]. 2012 [citado 2017 nov. 13];3(4):178-81. Disponível em: http://revista.portalcofen.gov.br/index.php/enfermagem/article/ view/379

8. Mininel VA, Felli VEA, Silva EJ, Torri Z, Abreu AP, Branco MTA. Workloads, strain processes and sickness absenteeism in nursing. Rev Latino Am Enfermagem [Internet]. 2013 [cited 2017 Nov 13];21(6):1290-7. Available from: http://www.scielo.br/pdf/rlae/v21n6/01041169-rlae-21-06-01290.pdf

9. Paschoalin HC, Griep RH, Lisboa MTL. A produção científica sobre o presenteísmo na enfermagem e suas repercussões no cuidado. Rev APS [Internet]. 2012 [citado 2017 nov. 13];15(3):306-11. Disponível em: https://aps.ufjf.emnuvens.com.br/aps/article/viewFile/1660/660

10. Umann J, Guido LA, Grazziano ES. Presenteeism in hospital nurses. Rev Latino Am Enfermagem [Internet]. 2012 [cited 2017 Nov 13];20(1):159-66. Available from: http://www.scielo.br/pdf/rlae/v20n1/21.pdf

11. Umann J, Silva RM, Guido LA. Assessment of stress, coping and presenteeism in a nephrology unit. J Nurs Educ Pract. 2014;4(7):165-74.

12. Lerner D, Amick BC, Lee JC, Rooney T, Rogers WH, Chang H, et al. Relationship of employee-reported word limitations of word productivity. Med Care. 2003;41(5):649-59.

13. Soárez PC, Kowalski CCG, Ferraz PC, Ciconelli RM. Tradução para português brasileiro e validação de um questionário de avaliação de produtividade. Rev Panam Salud Publica [Internet]. 2007 [citado 2017 nov. 13];22(1):21-8. Disponible en: http://www.scielosp.org/pdf/ rpsp/v22n1/a03v22n1.pdf

14. Dancey CP, Reidy J. Estatística sem matemática para psicologia. $5^{\mathrm{a}}$ ed. Porto Alegre: Penso; 2013.

15. Umann J, Guido LA, Silva RM. Stress, coping and presenteeism in nurses who assists critical and Potentially critical patients. Rev Esc Enferm USP [Internet]. 2014 [cited 2017 Nov 13];48(5):887-94. Available from: http://www.scielo.br/pdf/reeusp/v48n5/0080-6234reeusp-48-05-891.pdf

16. Errico A,Viotti S, Baratti A, Mottura B, Barocelli AP, Tagna M, et al. Low back pain and associated presenteeism among hospital nursing staff. J Occup Health. 2013;55(4):276-83.

17. Metsämuuronen R, Vilmunen MT, Kokki H, Kurttila M, Naaranlahti T, Saano S, et al. Ergonomics and skin and respiratory tract reactions related to antibiotic reconstitution among nurses and ward pharmacists. Drugs Ther Perspect. 2016;32(8):351-6.

18. Nassiri P, Heidari HR, Khadem M, Rahimifard H, Rostami E. Assessment of noise annoyance and its effects on healthcare staff based on sound pressure level and annoyance scale. Int J Occup Hyg [Internet]. 2014 [cited 2017 Nov 13];6(1):23-30. Available from: http://ijoh. tums.ac.ir/index.php/ijoh/article/view/93/93

19. Fernandes MC, Silva LMS, Moreira TMM, Silva MRF. Factors involved in the management of nursing care: a descriptive study. Online Braz J Nurs [Internet]. 2013 [cited 2017 Nov 13];12(2):522-33. Available from: http://www.objnursing.uff.br/index.php/nursing/article/ view $/ 4081 / \mathrm{html}$

20. Karino ME, Felli VEA, Sarquis LMM, Santana LL, Silva SR, Teixeira RC. Workloads and strain processes of nursing workers at teaching hospital. Ciênc Cuid Saúde [Internet]. 2015 [cited 2017 Nov 13];14(2):1011-8. Available from: http://periodicos.uem.br/ojs/index.php/ CiencCuidSaude/article/view/21603/14751

21. Martinez LF, Ferreira Al. Sick at work: presenteeism among nurses in a Portuguese public hospital. Stress Health. 2012;28(4):297-304.

22. Rezende LCM, Leite KNS, Santos SR, Monteiro LC, Costa MBS, Santos FX. Acidentes de trabalho e suas repercussões na saúde dos profissionais de enfermagem. Rev Baiana Enferm [Internet]. 2015 [citado 2017 nov. 13];29(4):307-17. Disponível em: https://portalseer. ufba.br/index.php/enfermagem/article/view/13559 